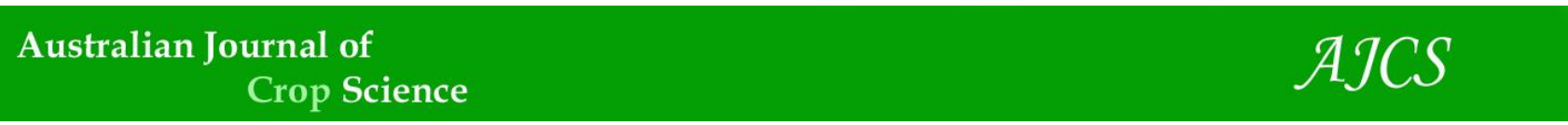

AJCS 15(04):610-617 (2021)

ISSN:1835-2707

doi: 10.21475/ajcs.21.15.04.p3100

\title{
Performance of pre-emergence herbicides in weed competition and soybean
} agronomic components

\author{
Marcelo de Sousa da Silva ${ }^{1 *}$, Tiago Vieira da Costa ${ }^{1}$, José Augusto Lima Furtado ${ }^{1}$, Jarlyson Bruno Costa \\ Souza ${ }^{2}$, Eduardo Arouche da Silva ${ }^{3}$, Lusiane de Sousa Ferreira ${ }^{4}$, Carlos Augusto Alves Cardozo Silva ${ }^{3}$, \\ Edmilson Igor Bernardo Almeida ${ }^{1}$, Washington da Silva Sousa ${ }^{1}$, Leonardo Bernardes Taverny de Oliveira ${ }^{1}$, \\ José Roberto Brito freitas ${ }^{1}$, Job Teixeira de Oliveira ${ }^{1}$
}

\author{
${ }^{1}$ Universidade Federal do Maranhão, 65500-000, Chapadinha-MA, Brazil \\ 2Universidade Estadual Paulista Júlio Mesquita Filho, 14884-900, Jaboticabal-SP, Brazil \\ ${ }^{3}$ Universidade de São Paulo, 13418-900, Piracicaba-SP, Brazil \\ ${ }^{4}$ Universidade Federal do Espírito Santo, 29500-000, Alegres-ES, Brazil
}

*Corresponding author: marcelosousamj@hotmail.com

\begin{abstract}
Soybean is the most important oilseed over the world. Different factors interfere in its development, among them, the interference of weeds. Thus, the objective was to analyze the performance of pre-emergence herbicides on the weed competition and agronomic components of soybean. For this, an experiment was carried out in commercial farming. The experimental design was in randomized blocks with three treatments and nine repetitions. The following treatments were tested: S-metolachlor $(1,152 \mathrm{~g}$ a.i. ha-1 $^{-1}$ ); diclosulam ( $35 \mathrm{~g}$ a.i. ha-1 $42 \mathrm{~g}$ a.i. ha- $\left.{ }^{-1}\right)+$ imazethapyr (164.8 $\mathrm{g}$ a.i. ha- ${ }^{-1}$ ). Two phytosociological surveys were carried out at 21 and 32 days after sowing (DAS) for controlling the weed competition. At 14, 21, 32, and 37 DAS, stem height and diameter were analyzed, while at $115 \mathrm{DAS}$, the production components were estimated. The application of S-metolachlor $(1,152 \mathrm{~g}$ a.i. ha-1) was efficient for pre-emergence weed control of weed competition in commercial soybean crops. Through this treatment, the conventional cultivar Ansc 89109 produced between 130,5 and 255,8 kg per hectare, this result is superior those obtained in plots treated with diclosulam ( $35 \mathrm{~g}$ a.i ha-1) + imazethapyr (164.8 $\mathrm{g}$ a.i. ha-1) and diclosulam (42 $\mathrm{g}$ a.i. ha-1) + imazethapyr (164.8 $\mathrm{g}$ a.i. ha$\left.{ }^{1}\right)$. Thus, the application of higher-doses of diclosulam (42 $\mathrm{g}$ a.i. ha-1) in a mixture with imazethapyr $\left(164.8 \mathrm{~g} \mathrm{a.i.} \mathrm{ha-}^{-1}\right)$ is not recommended since it presents eminent agronomic, environmental, and economic risks.
\end{abstract}

Keywords: Glycine max. (L.) Merril. Doses. Phytosociology. Productivity.

Abbreviations: g a.i. ha-1_ grams of active ingredient per hectare; DAS_days after sowing; kg_kilogram.

Introduction

Soybean (Glycine max. (L.) Merril) is the most important oilseed in the world. Brazil presents a considerable relevance in this scenario due to the annual increases in planted area and to the recent record production achieved in the 2017/2018 harvest, estimated at 119.3 million tons. For the 2019/20 harvest, the production estimate showed being promising, 120.4 million tons, which is higher than the country's record production (CONAB, 2019).

In the Maranhão state (MA), the increase in production in recent years has given it the position of second largest Northeastern soy producer. In 2018/2019, the state produced 2,916.8 tons, with a harvested area of 992.1 hectares and average productivity of $2,940 \mathrm{~kg} \mathrm{ha}^{-1}$. In the southern region of the state, the highest production of soy is concentrated, especially in Balsas (MA), which obtained a production of 616.7 thousand tons in the 2017/2018 harvest. The eastern mesoregion of Maranhão presents about $13 \%$ of the planted area in the state, with emphasis on the municipality of Brejo (Maranhão state), which was ranked among the ten largest soy producers in Maranhão, with a production of 73.3 thousand tons in $2017 / 2018$ (CONAB, 2019; IBGE, 2018).

The soybean crop influences many sectors, so there are large investments in research aimed at optimizing its productivity. However, this crop is impacted by multiple factors, including weed interference (Gazola et al., 2016). Weeds affect the crop mainly due to water, light, and nutrients competition, and, depending on the level of infestation and species, it can endanger the harvesting operation and the grain quality (Bueno et al., 2013).

Thereby, the study on phytosociological weeds in crops becomes a key tool to analyze the impacts that agricultural practices and management systems have on the dynamics of occupation and expansion of weed in crops (Fialho et al., 2011). Phytosociological studies provide specific information for each weed species, such as density, frequency, abundance, and importance value (Adegas et al., 2010). Through these indicators, efficiency in control strategies can be obtained, mainly chemical control that is one of the most used in large cultivation areas (Gazola et al., 2016). 
The pre-emergence chemical control lets the use of herbicides with a long-lasting residual effect preventing new emergence flows from the weed seed bank during the crop establishment; thus, at the juvenile phase, infraspecific or interspecific competition is avoided, while post-emergence control is promoted, mainly in conventional cultivars, if required (Sanchotene et al., 2017).

The selection of effective pre-emergence molecules for each situation depends primarily on their effective control and selectivity. Based on that, this study aimed to analyze the effect of three pre-emergence treatments on weed suppression and agronomic components of soybeans.

\section{Results and Discussion}

\section{Growth of soybean plants}

There was no statistical difference between the treatments analyzed for plant height and stem diameter. However, it was observed a significant effect on evaluation periods, showing that there was no interference in the growing crop, regardless of the pre-emergence treatment applied (Table 1).

Similar results were obtained by Aisenberg (2015) when studying physiological attributes and weed control by application of herbicides in soybeans; this study was conducted in the municipality of Capão do Leão (Rio Grande do Sul state). The author did not observe any difference between the herbicides S-metolachlor and diclosulam concerning the culture height. Likewise, Vidal et al. (1999), when testing different acetolactate synthase (ALS) inhibiting herbicides, including imazethapyr applied in the soybean flowering phase, did not observe any differences between stem diameter and plant height.

In a study conducted by Bianchi et al. (2011), they pointed out that the crop height can affect its ability to compete with weeds because crops with higher stature generally have greater soil coverage and suppression of solar radiation available to weeds, with a consequent reduction in weed competition on the critical phase (Lamengo et al., 2013). In turn, Kappes et al. (2012) highlighted that the stem diameter is an important vegetative character since it indicates the susceptibility of plants to lodging.

The results revealed that all treatments had plants with similar heights; therefore, the variations that occurred on the production yield may be related to the effects of the molecules on the seed bank and weed growth.

\section{Phytosociological indices of weed species according to pre- emergence treatment}

The results obtained by the application of S-metolachlor $(1,152 \mathrm{~g}$ a.i. ha-1) at 21 DAS, expressed the occurrence of six species belonging to five families (Table 2).

The species, Mollugo verticillata L., Eragrostis maypurensis (Kunth) Stued, and Cenchrus echinatus L., were the most important (IVI): $118.26,84.49$ and 54.84 , respectively (Table 2). Lopes et al. (2020a) found similar results for the IVI of Mollugo verticillata L., when characterizing the spatial distribution of seed dissemination bank in Chapadinha (Maranhão state).

The effect of S-metalochlor on the species Mollugo verticillata $\mathrm{L}$. was not effective; this result may be justified because it is a selective molecule to this species. According to Nunes and Vidal (2008), S-metolachlor consists of a nonionizable chemical product, belonging to the chemical group of chloroacetanilides, selective and indicated for the control of monocotyledons and commelinaceae in pre-emergence. However, there was no expected control over monocots and Commelina benghalensis L. These results corroborate with Freitas et al. (2006) when studying the management of weeds in cotton culture with S-metolachlor and trifloxysulfuron-sodium in conventional planting system. They considered the species Commelina benghalensis $\mathrm{L}$. as the second most important species; moreover, they observed the persistence in the occurrence of species of the Poaceae family; this may be related to the behavior of the herbicide into the soil, dose, and application technology used.

At 32 DAS, a decrease in the number of monocotyledonous species and a higher occurrence of dicotyledonous species, mainly Chamaesyce hyssopifolia (L.) Small, (105.41) Mollugo verticillata L. (100.69), Sida rhombifolia L. (24.41) (Table 2) was observed. Figure 3 shows a comparison between the infestation of mono and dicotyledons, at 21 and 32 DAS, in a plot treated with the pre-emergence S-metolachlor.

The findings of this study demonstrated that at 21 DAS, 141 monocotyledonous individuals were identified, with a decrease of $72.35 \%$ at 32 DAS, which is possibly due to the residual effect of S-metolachlor. According to Inoue et al. (2011), it extends up to 54 days after application in sandy texture soils and up to 80 days in clay soils. Thus, it may have resulted from the positive, selective, and systemic effect of the post-emergence molecule clethodim, applied to the 25 DAS, on monocotyledonous species (Radwam, 2012).

At 21 DAS, 151 dicotyledonous individuals with a density of 16.77 plants $\mathrm{m}^{-2}$ were observed. This amount was equivalent to monocotyledonous (141). Although, at 32 DAS, there was a drastic progression (320.53\%) in the number of dicotyledonous compared to 21 DAS. Furthermore, when compared to the number of monocots, the infestation of dicots was $1,241.03 \%$ higher at 32 DAS. It may be related to the low selectivity of herbicides for dicots, considering that the main crop belongs to this same group.

Corroborating these results, Souza et al. (2014) and Machado et al. (2016), when testing response doses of ACCase and S-metolachlor-inhibiting herbicides on dicotyledonous weeds, did not obtain positive control effects. In this sense, the producer must have more careful handling in the pre-planting, with further attention to the rotation of active principles and the adoption of cultural practices, in order to inhibit dicotyledonous weeds and their consequent seed dissemination bank.

The species with the highest importance value index (IVI) in the plot treated with the application of diclosulam ( $35 \mathrm{~g}$ a.i. ha $^{-1}$ ) + imazethapyr (164.8 g a.i. ha ${ }^{-1}$ ) were Mollugo verticillata L., Cyperus iria L., and Sida rhombifolia L., at 21 DAS (Table 3).

At 21 DAS, the species with the highest importance value index (IVI) in the plot treated with the application of diclosulam (35 g a.i. ha-1) + imazethapyr (164.8 g a.i. ha ${ }^{-1}$ ), were Mollugo verticillata L., Cyperus iria L., and Sida rhombifolia L. (Table 3). This result was in line with the phytosociological study carried out by Cardoso et al. (2013) in cassava culture, in the municipality of Vitória da Conquista (Bahia state). The authors noticed the species Sida rhombifolia $\mathrm{L}$. and Mollugo verticillata $\mathrm{L}$. among ten species with the highest IVI up to 35 days after crop planting.

The species occurring in this treatment showed higher values for the average number of individuals (IND), density (D), and abundance (A) when compared to the results 
presented in the treatment with S-metolachlor, except for the species Eragrostis maypurensis (Kunth) Stued (Table 3). According to Oliveira and Freitas (2008), the difference in phytosociological indexes of weeds in the same crop is associated with the management methods used in the crop. Therefore, although there is no interference with the vegetative characteristics of the crop, the pre-emergence molecules had different effects on the suppression of weed competition.

At 32 DAS, the positive effects of the application of the postemergence clethodim over the reduction of phytosociological indices of monocotyledonous were observed. However, there were new dicotyledonous species: Chamaesyce hyssopifolia (L.) Small and Phyllanthus niruri L., and an increase in IVIs of dicotyledonous (Table 3 ). The less monocotyledonous infestation was observed at 21 and 32 DAS when compared to treatment with S-metolachlor (Figures 1 and 2).

The imazethapyr likely provided an increase in the control spectrum of monocotyledonous through ALS inhibition. It corroborates with Fialho et al. (2011), who indicated the use of acetolactate synthase (ALS) inhibitors in the grasses control in soybean culture, as they shut down the synthesis of proteins, proving interference with DNA synthesis and cell growth.

At 32 DAS, a decrease in monocotyledonous species was observed, which may be associated with the residual effect of the pre-emergence mixture diclosulam (35 $\mathrm{g}$ a.i ha-1) + imazethapyr (164.8 $\mathrm{g}$ a.i. ha-1) and efficiency of clethodim in post-emergence for the control of monocotyledonous. Nevertheless, it is not effective on dicotyledonous, although diclosulam is selective and recommended for the control of dicots on soybeans, as highlighted by Rodrigues and Almeida (2011) and Mendes et al. (2019). These species showed predominance in the area, with a worrying increase in infestation at 32 DAS. It probably induced competitive advantages of these weeds over the soybean crop in its critical control phase, especially concerning the species Commelina benghalensis L., which increased the IVI by $34.39 \%$ between the first and second phytosociological study. Furthermore, new species emerged, Chamaesyce hyssopifolia (L.) Small and Phyllanthus niruri L., with IVIs of 20.89 and 11.71 , respectively.

The application of the superdoses of diclosulam ( $42 \mathrm{~g}$ a.i. ha ${ }^{1}$ ) in mixture with the same dose of imazethapyr (164.8 g a.i. $\mathrm{ha}^{-1}$ ) of the earlier treatment was more efficient in the control of Mollugo verticillata $\mathrm{L}$. and Commelina benghalensis L., as observed on IVI data (Table 4).

Among the four families found, the Poaceae exhibited the highest IVI. It corroborates the results obtained by Paes (2010), who ranked this family as the one with the highest IVI (114) in a phytosociological study on the culture of sunflower submitted to different managements in Campos dos Goytacazes (Rio de Janeiro state). Likewise, Martins et al. (2019) found little effect of diclosulam applied in preemergence on grasses, especially from the Poaceae family. This fact can be explained by the diclosulam control spectrum indicated for the control of dicots.

About the imazethapyr, Silva et al. (2010) report that the herbicide only reached $56 \%$ control at 28 days after the application of the product on weeds of the Poaceae family. These results explain the highest phytosociological indexes obtained at 21 DAS for this family, with the application of diclosulam (42 g a.i. ha ${ }^{-1}$ ) + imazethapyr (164.8 g a.i. ha ${ }^{-1}$ ).
At 32 DAS, a significant number of species were observed in the area, mostly dicotyledonous (Figure 3).

The species Mollugo verticillata L. exhibited the highest IVI (132.06) and a density of 85.67 plants $\mathrm{m}^{-2}$, which shows a high infestation of this species (Table 4). Moreover, Lopes et al. (2020b), when studying the phytosociology of the seed bank in Chapadinha (Maranhão state), observed that Mollugo verticillata $\mathrm{L}$. presented greater relative importance (70\%), allowing to infer about the adequate adaptation of this species to the edaphoclimatic conditions in the East of Maranhão state.

The results revealed that the application of an elevated dose of diclosulam induced a high initial infestation of mono and dicotyledonous when compared to the other treatments (Figure 3). The monocotyledon infestation with the application of diclosulam (42 $\mathrm{g}^{\text {a.i. }}$ ha-1 $^{-1}$ ) + imazethapyr (164.8 g a.i. ha $^{-1}$ ) was $503.55 \%$ and $710 \%$ higher than that obtained with S-metolachlor and diclosulam (35 g a.i. ha-1) + imazethapyr (164.8 g a.i. ha-1), at 21 DAS. Alike, it was $938.45 \%$ and $546.27 \%$ higher than these same treatments at 32 DAS.

Probably this result is due to the antagonism effect of the application of elevated doses of diclosulam on imazethapyr. The findings in this study was in line with the results found by Souza et al. (2014) and Damalas (2004), who recommended avoiding the application of excessive doses due to the risk of unexpected mix interactions, as well as inducing weed resistance to these herbicides, due to increased selection pressure.

In the lowest dose ( $35 \mathrm{~g}$ a.i. ha-1), the use of superdoses of diclosulam did not present selective control as expected over dicotyledons. The infestations were $177.69 \%$ and $239.56 \%$ superior to other treatments. It is worthy to note, that the control was inferior to the application of $35 \mathrm{~g}$ a.i. ha1 , inferring about the negative socioeconomic and environmental risks to be caused by the superdoses of diclosulam, in the medium and long term of use.

The occurrence of Cyperus iria L. was persistent in all treatments analyzed. Despite lower density and IVI, compared to other species at 21 DAS, the application of the post-emergence clethodim did not result in efficient control until 32 DAS. This is alarming, as it is a monocot, whose positive effect of pre- emergence and complementary postemergence herbicides was expected to be suppressed, mainly for ALS inhibiting active ingredients, like imazethapyr and diclosulam. This result was considered alarming as it is a monocot, whose positive effect of pre-emergence and complementary post-emergence herbicides was expected to be suppressed, mainly for ALS inhibiting active ingredients, like imazethapyr and diclosulam.

In this sense, it should be highlighted that there are biotypes of Cyperus iria L. with crossed resistance to ALS inhibitors since 2010, in the United States (Riar et al., 2015), and six years ago in Brazil (Chiapinotto et al., 2017). Thus, monitoring of this species in agriculture in future research is indicated, as well as the adoption of preventive measures, such as the succession/rotation of crops, rotation of active ingredients, cleaning of machinery, among other management aspects punctuated by Salomão et al. (2020).

\section{Productivity}

The Table 5 presents information about the number of plants per meter (NP $\mathrm{m}^{-1}$ ), number of pods per plant (NPo), number of grains per plant (NG), and soybean productivity (PROD). Among these variables, only productivity did not 
Table 1. Effect of pre-emergence molecules on plant height (PH) and stem diameter (SD) of soybeans at 14, 21, 32, and 37 days after sowing (DAS).

\begin{tabular}{|c|c|c|c|c|}
\hline Pre-emergence & 14 DAS & 21 DAS & 32 DAS & 37 DAS \\
\hline \multicolumn{5}{|l|}{$\mathrm{PH}(\mathrm{cm})$} \\
\hline S-metolachlor & 11.91Ad & $14.90 \mathrm{Ac}$ & $27.42 \mathrm{Ab}$ & $34.55 \mathrm{Aa}$ \\
\hline Diclosulam (35 g a.i. ha ${ }^{-1}$ )+Imazetapyr & 11.38Ad & $14.53 \mathrm{Ac}$ & $26.83 \mathrm{Ab}$ & $32.81 \mathrm{Aa}$ \\
\hline Diclosulam (42 g a.i. ha-1)+Imazetapyr & 11.44Ad & $14.40 \mathrm{Ac}$ & $26.81 \mathrm{Ab}$ & 33.82Aa \\
\hline Coefficient of variation a (\%) & 7.61 & - & - & - \\
\hline Coefficient of variation b (\%) & 5.63 & - & - & - \\
\hline \multicolumn{5}{|l|}{$\mathrm{SD}(\mathrm{mm})$} \\
\hline S-metolachlor & $1.91 \mathrm{Ad}$ & $2.60 \mathrm{Ac}$ & $3.81 \mathrm{Ab}$ & $4.48 \mathrm{Aa}$ \\
\hline Diclosulam (35 g a.i. ha-1)+Imazetapyr & $1.84 \mathrm{Ad}$ & 2.87Ac & $3.87 \mathrm{Ab}$ & $4.35 \mathrm{Aa}$ \\
\hline Diclosulam (42 g a.i. ha ${ }^{-1}$ )+Imazetapyr & 1.93Ad & $2.72 A c$ & $3.46 \mathrm{Ab}$ & $4.10 \mathrm{Aa}$ \\
\hline Coefficient of variation a (\%) & 13.59 & - & - & - \\
\hline Coefficient of variation b (\%) & 12.58 & - & - & - \\
\hline
\end{tabular}

Coefficient of variation $a=$ tratament variation coefficient. Coefficient of variation $b=$ coefficient of variation of the evaluation period. Means followed by the equal capital letters in the column and small letters in the same line do not differ by the Tukey test at $5 \%$ probability. $\mathrm{PH}=$ plant height; $\mathrm{SD}=$ stem diameter.

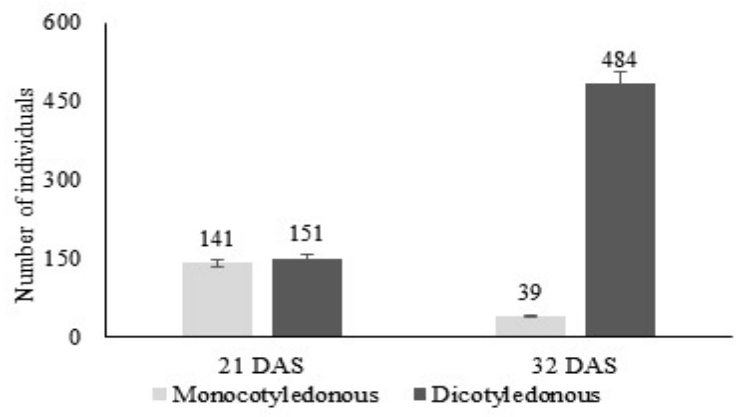

Fig 1. Effect of the S-metolachlor molecule on mono and dicotyledonous weeds in a commercial soybean plot at 21 and 32 days after sowing (DAS).

Table 2. Phytosociological indices of weed species occurring at 21 and 32 days after sowing (DAS) in commercial soybean crop treated with Smetolachlor.

\begin{tabular}{|c|c|c|c|c|c|c|c|c|c|c|c|}
\hline Family & Scientific name & IND & ID & $\mathrm{D}\left(\mathrm{pl} . \mathrm{m}^{-2}\right)$ & $\operatorname{Dr}(\%)$ & $\mathrm{F}(\%)$ & $\operatorname{Fr}(\%)$ & $\mathrm{A}$ & $\operatorname{Ar}(\%)$ & IVI & $\operatorname{Ir}(\%)$ \\
\hline \multicolumn{12}{|c|}{ S-metolachlor $\left(1,152 \mathrm{~g}\right.$ a.i. $\left.\mathrm{ha}^{-1}\right)-21 \mathrm{DAS}$} \\
\hline Molluginaceae & Mollugo verticillata $\mathrm{L}$. & 3.94 & 4.84 & 15.78 & 48.63 & 80.56 & 48.63 & 4.90 & 30.44 & 118.26 & 39.42 \\
\hline Poaceae & Eragrostis maypurensis & & & & & & & & & & \\
\hline Poaceae & $\begin{array}{l}\text { (Kunth) Stued } \\
\text { Cenchrus echinatus L. }\end{array}$ & $\begin{array}{l}2.39 \\
1.25\end{array}$ & $\begin{array}{l}6.47 \\
2.09\end{array}$ & $\begin{array}{l}9.56 \\
5.00\end{array}$ & $\begin{array}{l}29.45 \\
15.41\end{array}$ & $\begin{array}{l}44.44 \\
47.22\end{array}$ & $\begin{array}{l}21.62 \\
22.97\end{array}$ & $\begin{array}{l}5.38 \\
2.65\end{array}$ & $\begin{array}{l}33.44 \\
16.46\end{array}$ & $\begin{array}{l}84.49 \\
54.84\end{array}$ & $\begin{array}{l}28.16 \\
18.28\end{array}$ \\
\hline Cyperaceae & Cyperus iria L. & 0.28 & 1.73 & 1.11 & 3.42 & 16.67 & 8.11 & 1.67 & 10.36 & 21.89 & 7.30 \\
\hline Commelinaceae & Commelina benghalensis $\mathrm{L}$. & 0.25 & 1.65 & 1.00 & 3.08 & 16.67 & 3.08 & 1.50 & 9.33 & 20.52 & 6.84 \\
\hline \multicolumn{12}{|c|}{ S-metolachlor $\left(1,152 \mathrm{~g}\right.$ a.i. $\left.\mathrm{ha}^{-1}\right)-32$ DAS } \\
\hline & Chamaesyce hyssopifolia (L.) & & & & & & & & & & \\
\hline Euphorbeacea & Small & 6.47 & 9.42 & 25.89 & 44.55 & 77.78 & 30.11 & 8.32 & 30.75 & 105.41 & 35.14 \\
\hline Molluginaceae & Mollugo verticillata $\mathrm{L}$. & 6.03 & 7.72 & 24.11 & 41.49 & 86.11 & 33.33 & 7.00 & 25.87 & 100.69 & 33.56 \\
\hline Malvaceae & Sida rhombifolia L. & 0.67 & 2.35 & 2.67 & 4.59 & 27.78 & 10.75 & 2.40 & 8.87 & 24.41 & 8.07 \\
\hline Poaceae & Cenchrus echinatus L. & 0.58 & 2.33 & 2.33 & 4.02 & 30.56 & 11.83 & 1.91 & 7.06 & 22.90 & 7.63 \\
\hline Cyperaceae & Cyperus meyenianus Kunth. & 0.33 & 8.18 & 1.33 & 2.29 & 8.33 & 3.23 & 4.00 & 14.78 & 20.30 & 6.77 \\
\hline Commelinaceae & Commelina benghalensis $\mathrm{L}$. & 0.28 & 1.53 & 1.11 & 1.91 & 19.44 & 7.53 & 1.43 & 5.28 & 14.72 & 4.91 \\
\hline Cyperaceae & Cyperus iria L. & 0.17 & 1.50 & 0.67 & 1.15 & 8.33 & 3.23 & 2.00 & 7.39 & 11.76 & 3.92 \\
\hline
\end{tabular}

$\mathrm{IND}=$ Average number of individuals per parcel; $\mathrm{DI}=$ dispersion index; $\mathrm{D}=$ density; $\mathrm{Dr}=$ relative density; $\mathrm{F}=$ frequency; $\mathrm{Fr}=$ relative frequency; $\mathrm{A}=\mathrm{abundance} ; \mathrm{Ar}=$ relative abundance; $\mathrm{IVI}=\mathrm{importance}$ value index; Ir = relative importance.

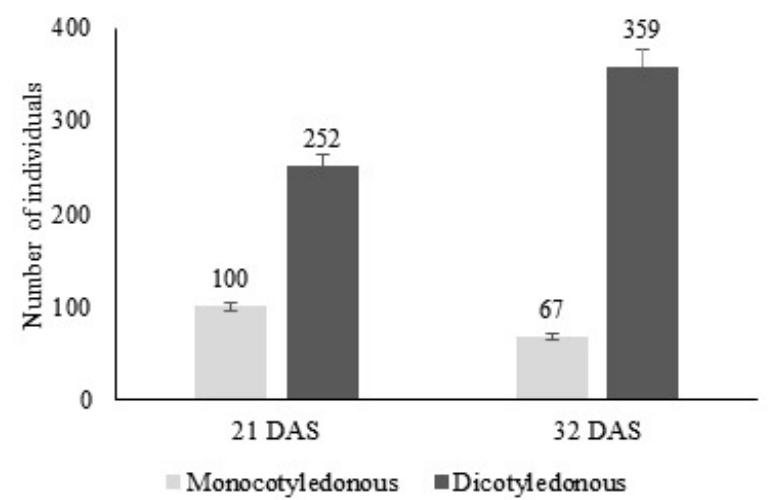

Fig 2. Effect of the diclosulam molecule $\left(35 \mathrm{~g}\right.$ a.i. ha $\left.{ }^{-1}\right)+$ imazethapyr on mono and dicotyledonous weeds in a commercial soybean plot at 21 and 32 days after sowing (DAS). 
Table 3. Phytosociological indices of weed species in commercial soybean crops, with diclosulam $35 \mathrm{~g}^{\text {a.i. }}$ ha $^{-1}+\mathrm{imazethapyr} 164.8 \mathrm{~g}$ a.i. ha-1, to 21 days after sowing (DAS).

\begin{tabular}{|c|c|c|c|c|c|c|c|c|c|c|c|}
\hline Family & Scientific name & IND & $\mathrm{DI}$ & $\mathrm{D}\left(\mathrm{pl} . \mathrm{m}^{-2}\right)$ & $\operatorname{Dr}(\%)$ & $\mathrm{F}(\%)$ & $\operatorname{Fr}(\%)$ & A & $\operatorname{Ar}(\%)$ & $\mathrm{IVI}$ & $\operatorname{lr}(\%)$ \\
\hline \multicolumn{12}{|c|}{ Diclosulam (35 g a.i. ha-1) + imazethapyr $(164,8$ g a.i. ha-1) - 21 DAS } \\
\hline Molluginaceae & Mollugo verticillata $\mathrm{L}$. & 5.5 & 6.16 & 24.67 & 63.07 & 88.89 & 45.71 & 6.94 & 37.61 & 146.39 & 48.80 \\
\hline Cyperaceae & Cyperus iria L. & 1.86 & 14.04 & 9.67 & 24.72 & 52.78 & 27.14 & 4.58 & 24.82 & 76.68 & 25.56 \\
\hline Malvaceae & Sida rhombifolia L. & 2.89 & 0.97 & 2.22 & 5.68 & 16.67 & 8.57 & 3.33 & 18.07 & 32.32 & 10.77 \\
\hline & maypurensis & & & & & & & & & & \\
\hline Poaceae & (Kunth) Stued & 0.11 & 7.61 & 1.44 & 3.69 & 16.67 & 8.57 & 2.17 & 11.75 & 24.01 & 8.00 \\
\hline Commelinaceae & Commelina benghalensis L. & 1.08 & 0.49 & 1.11 & 2.84 & 19.44 & 10.00 & 1.43 & 7.75 & 20.59 & 6.86 \\
\hline \multicolumn{12}{|c|}{ Diclosulam (35 g a.i. ha-1) + imazethapyr (164.8 g a.i. ha-1) - 32 DAS } \\
\hline Molluginaceae & Mollugo verticillata $\mathrm{L}$. & 5.5 & 6.54 & 22 & 46.48 & 80.56 & 33.33 & 6.83 & 28.91 & 108.72 & 36.24 \\
\hline Malvaceae & Sida rhombifolia L. & 2.89 & 4.52 & 11.56 & 24.41 & 63.89 & 26.44 & 4.52 & 19.15 & 70.00 & 23.33 \\
\hline Cyperaceae & Cyperus iria L. & 1.86 & 13.7 & 7.44 & 15.73 & 41.67 & 17.24 & 4.47 & 18.91 & 51.88 & 17.29 \\
\hline Commelinaceae & $\begin{array}{l}\text { Commelina benghalensis L. } \\
\text { Chamaesyce hyssopifolia (L.) }\end{array}$ & 1.08 & 5.95 & 4.33 & 9.15 & 36.11 & 14.94 & 3.00 & 12.70 & 36.80 & 12.27 \\
\hline Euphorbeacea & Small & 0.39 & 6 & 1.56 & 3.29 & 13.89 & 5.75 & 2.80 & 11.86 & 20.89 & 6.96 \\
\hline Phyllanthaceae & Phyllanthus niruri L. & 0.11 & 21 & 0.44 & 0.94 & 5.56 & 2.30 & 2.00 & 8.47 & 11.71 & 3.90 \\
\hline
\end{tabular}

$\mathrm{IND}=$ Average number of individuals per parcel; $\mathrm{DI}=$ dispersion index; $\mathrm{D}=$ density; $\mathrm{Dr}=$ relative density; $\mathrm{F}=$ frequency; $\mathrm{Fr}=$ relative frequency; $\mathrm{A}=$ abundance; $\mathrm{Ar}=$ relative abundance; $\mathrm{IVI}=\mathrm{importance}$ value index; $\mathrm{Ir}$ $=$ relative importance.

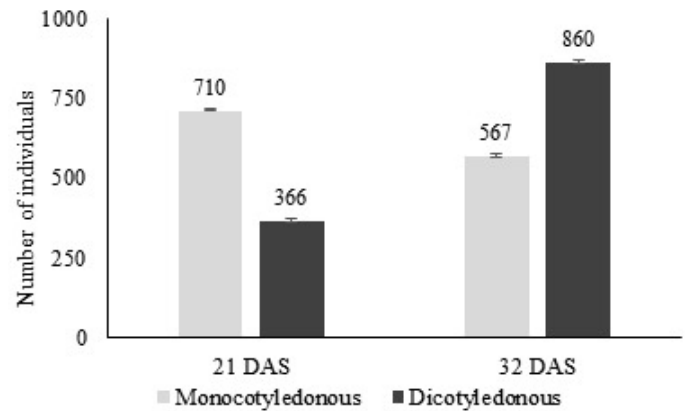

Fig 3. Effect of the diclosulam molecule ( $42 \mathrm{~g}$ a.i. $\left.\mathrm{ha}^{-1}\right)+\left(\right.$ imazethapyr $164.8 \mathrm{~g}$ a.i. ha ${ }^{-1}$ ) on mono and dicotyledonous weeds in a commercial soybean plot at 21 and 32 days after sowing (DAS).

Table 4. Phytosociological indices of weed species occurring at 21 and 32 days after sowing (DAS), in commercial soybean tract treated with diclosulam $42 \mathrm{~g}$ a.i. ha-1 + imazethapyr $164.8 \mathrm{~g}$ a.i. ha- ${ }^{-1}$.

\begin{tabular}{|c|c|c|c|c|c|c|c|c|c|c|c|}
\hline Family & Scientific name & IND & $\mathrm{DI}$ & $\mathrm{D}\left(\mathrm{pl} . \mathrm{m}^{-2}\right)$ & $\operatorname{Dr}(\%)$ & $F(\%)$ & $\operatorname{Fr}(\%)$ & A & $\operatorname{Ar}(\%)$ & IVI & $\operatorname{Ir}(\%)$ \\
\hline \multicolumn{12}{|c|}{ Diclosulam (42 g a.i. ha-1) + imazethapyr (164.8 g a.i. ha-1) - 21 DAS } \\
\hline Poaceae & $\begin{array}{l}\text { Eragrostis maypurensis } \\
\text { (Kunth) Stued }\end{array}$ & 15.25 & 10.97 & 61.00 & 51.08 & 94.44 & 32.38 & 16.15 & 42.59 & 125.99 & 43.61 \\
\hline Molluginaceae & Mollugo verticillata $\mathrm{L}$. & 9.94 & 6.03 & 39.78 & 33.27 & 88.89 & 30.48 & 11.19 & 29.51 & 93.26 & 32.28 \\
\hline Poaceae & Cenchrus echinatus L. & 3.42 & 3.11 & 13.67 & 11.43 & 66.67 & 22.86 & 5.13 & 13.52 & 47.81 & 15.94 \\
\hline Cyperaceae & Cyperus iria L. & 1.06 & 4.60 & 4.22 & 3.53 & 30.56 & 10.48 & 3,45 & 9.11 & 23.12 & 7.71 \\
\hline Commelinaceae & Commelina benghalensis $\mathrm{L}$. & 0.22 & 2.53 & 0.89 & 0.74 & 11.11 & 3.81 & 2.00 & 5.58 & 9.83 & 3.28 \\
\hline \multicolumn{12}{|c|}{ Diclosulam (42 g a.i. ha-1) + imazethapyr $(164.8 \mathrm{~g}$ a.i. ha-1) - 32 DAS } \\
\hline Molluginaceae & Mollugo verticillata $L$. & 21.42 & 7.28 & 85.67 & 54.03 & 100.00 & 40.00 & 21.42 & 38.03 & 132.06 & 44.02 \\
\hline Poaceae & $\begin{array}{l}\text { Eragrostis maypurensis } \\
\text { (Kunth) Stued }\end{array}$ & 15.17 & 8.77 & 60.67 & 38.26 & 80.56 & 32.22 & 18.83 & 33.43 & 103.91 & 34.64 \\
\hline Rubiaceae & Spermacoce alata (Aubl.) DC. & 2.08 & 18.31 & 8.33 & 5.26 & 25.00 & 10.00 & 8.33 & 14.80 & 30.05 & 10.02 \\
\hline Cyperaceae & Cyperus iria L. & 0.58 & 2.91 & 2.33 & 1.47 & 30.56 & 12.22 & 1.91 & 3.39 & 17.08 & 5.69 \\
\hline Boraginaceae & $\begin{array}{l}\text { Heliotropium indicumL. } \\
\text { Richardia grandiflora (Cham. }\end{array}$ & 0.19 & 2.53 & 0.78 & 0.49 & 8.33 & 3.33 & 2.33 & 4.14 & 7.97 & 2.66 \\
\hline Rubiaceae & \& Schltdl.) Steud. & 0.19 & 3.95 & 0.78 & 0.49 & 5.56 & 2.22 & 3.50 & 6.21 & 8.93 & 2.98 \\
\hline
\end{tabular}

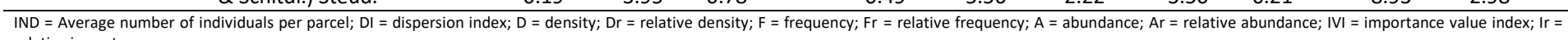
relative importance.

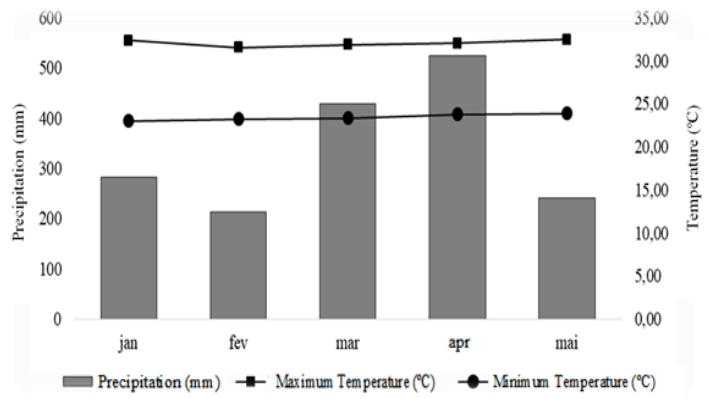

Figure 4. Precipitation data $(\mathrm{mm})$ and minimum and maximum temperature $\left({ }^{\circ} \mathrm{C}\right)$ registered for the eastern mesoregion of Maranhão, between January and May 2019. Source: INMET, 2019.

Table 5. Effect of the application of different pre-emergence herbicides on the number of plants (NP $\mathrm{m}^{-1}$ ), number of pods per plant (NPo), number of grains per plant (NG) and productivity (PROD, $\mathrm{kg} \mathrm{ha}^{-1}$ ). 


\begin{tabular}{|c|c|c|c|c|}
\hline Pre-emergence & $\mathrm{NP} \mathrm{m}^{-1}$ & NPo & NG & PROD \\
\hline S-metolachlor & $12.78 \mathrm{~A}$ & $656.55 \mathrm{~A}$ & $1405.44 \mathrm{~A}$ & $3,621.8 \mathrm{~A}$ \\
\hline Diclosulam (35 g a.i. ha $\left.{ }^{-1}\right)+$ Imazethapyr & $12.33 \mathrm{AB}$ & $611.33 \mathrm{AB}$ & 1252.11AB & $3,491.3 \mathrm{~A}$ \\
\hline Diclosulam (42 g a.i. ha $\left.{ }^{-1}\right)+$ Imazethapyr & $11.55 \mathrm{~B}$ & $586.00 \mathrm{~B}$ & $1136.22 \mathrm{~B}$ & $3,366.0 \mathrm{~A}$ \\
\hline CV (\%) & 7.77 & 8.99 & 11.92 & 9.90 \\
\hline
\end{tabular}

differ between treatments. There was a statistically significant difference for $\mathrm{NP} \mathrm{m}^{-1}, \mathrm{NPo}$, and NG between treatment with $\mathrm{S}$-metolachlor and treatment with diclosulam at its highest dose ( $42 \mathrm{~g}$ a.i. ha-1).

The number of plants was higher in plots treated with Smetolachlor and diclosulam + imazethapyr ( $35 \mathrm{~g}$ a.i. ha-1 ${ }^{-1}$, differing from the results presented by Martins et al. (2019), who did not observe any significant effect of different preemergence herbicides on this variable. Probably, the highest dose of diclosulam (42 $\mathrm{g}$ a.i. ha ${ }^{-1}$ ) may have caused a phytotoxic effect on soybean germination. This result is in line with those found by Rodrigues-Costa et al. (2011), who state that inadequate doses of herbicides, mainly preemergence ones, could compromise the selectivity, and consequently, the initial growth of the crop.

For the number of grains (NG) and pods (NPo) per plant, it was observed that the treatment with S-metolachlor had the highest means, differing statistically from the highest dose of diclosulam (42 $\mathrm{g}$ a.i. ha ${ }^{-1}$ ), which may have been influenced by the greater number of soybean plants per meter and lower weed competition estimated at 21 and 32 DAS. Similar results were found by Souza et al. (2019) when studying the agronomic performance of soybean under the interference of weed plants. These authors noticed a reduction in grain yield $(32 \%)$ in infested areas, especially by species of the Poaceae family.

Despite these variations in the production components, there was no greater statistical difference between treatments for productivity. These results matched those obtained in a study carried out by Sanchotene et al. (2017) when testing different pre-emergence herbicides to control Euphorbia heterophylla in soybean culture, did not observe a significant difference in productivity between treatment with S-metolachlor (1152 g a.i. ha-1) and diclosulam (35.28 g a.i. ha-1)

However, it is worth to emphasize that the use of Smetolachlor provided a yield of 130.5 and $255.8 \mathrm{~kg}$. ha-1 more than the application of diclosulam + imazethapyr in the two doses tested, this yield is equivalent to approximately 2 and 4 additional bags per hectare, respectively. Moreover, as the east of the state of Maranhão is an expanding agricultural frontier, the increase obtained is very significant for the producer. Nevertheless, given the limitations caused by edaphoclimatic instability on productive yield in the region, the average obtained was lower compared to other agricultural frontiers such as Bahia and Piauí, whose averages are 3,360 kg. ha-1 and 3,087 kg. ha-1 (CONAB, 2019).

Furthermore, the addition of $7 \mathrm{~g}$ a.i. ha ${ }^{-1}$ at the dose diclosulam mixed with imazethapyr was not effective in suppressing weeds, mainly dicotyledonous. It showed a production yield slightly lower than the lowest tested dose (35 g a.i. ha-1). Thus, this treatment should not be recommended to the producer for agronomic, environmental, and economic reasons.

Concerning the appearance or increase in the infestation of dicotyledon in the critical control period for all treatments tested, it was recommended adopting agricultural practices at the inter-harvest period and more efficient sweep tillage in pre-planting desiccation, which can be optimized by efficient use of application technology, dose calibration, and rotation of active ingredients.

On the other hand, this persistence of dicots may increase the seed bank in the soil and cause drastic negative effects on crop yield in the following years. It may occur mainly in conventional materials, in which the use of broad-spectrum molecules, such as glyphosate, is not recommended, as well as in crops where the application of glyphosate is not indicated due to the predominance of resistant genotypes.

\section{Materials and Methods}

\section{Conduction of study}

The experiment was conducted in a commercial crop located in the municipality of Brejo, in the state of Maranhão, Brazil, eastern Maranhense mesoregion, between January and May 2019. The geographic coordinates of the site are $03^{\circ} 42^{\prime} \mathrm{S}$ and $42^{\circ} 57^{\prime} \mathrm{O}$, at an altitude of $90 \mathrm{~m}$.

According to Dantas et al. (2014), the soil in the experimental area were classified as a typical Distrocoeso Yellow Argisol. According to the Köppen classification, the region's climate were classified as tropical warm and humid (Aw), with an average annual temperature above $27^{\circ} \mathrm{C}$ and average annual rainfall ranging from 1600 to $2000 \mathrm{~mm}$, with a rainy period between the months from January to June and drought between July to December, with annual relative humidity between 73 and $79 \%$ (Maranhão, 2002).

The data of precipitation, maximum and minimum temperature during the months of the experiment are shown in Figure 4, according to INMET (Portuguese acronym for Brazilian National Institute of. Meteorology) (INMET, 2019).

\section{Experimental design and pre-emergence treatments}

The experiment was carried out in a randomized block design (RBD), composed of three treatments, consisting of three pre-emergence treatments: S-metolachlor $(1,152 \mathrm{~g}$ a.i. $\left.h^{-1}\right)$, diclosulam (35 g a.i. ha-1) + imazethapyr $(164,8 \mathrm{~g}$ a.i. $\mathrm{ha}^{-1}$ ), and diclosulam (42 g a.i. ha-1 ${ }^{-1}$ imazethapyr $164.8 \mathrm{~g}$ a.i. $\left.\mathrm{ha}^{-1}\right)$, nine repetitions, and four lines of one linear meter per plot. The total area used was $15 \mathrm{~m}^{2}(3 \mathrm{~m} \times 5 \mathrm{~m})$, spaced $4 \mathrm{~m}$ apart. For crop evaluation, the four central lines of 1 linear meter of each plot were assessed.

Pre-planting desiccation was made 15 days before planting, by applying glyphosate $(2,477.1 \mathrm{~g}$ a.i. ha-1) + 2,4-D (1,476 g a.i. $\left.\mathrm{ha}^{-1}\right)$. The seeds were treated with abamectin nematicide ( $500 \mathrm{~g}$ a.i. $\left.\mathrm{L}^{-1}\right)$ in the dosage of $0.002 \mathrm{~L} \mathrm{kgv}^{-1}$, fungicide $(20 \mathrm{~g}$ a.i. $\mathrm{L}^{-1}$ of metalaxil-M $+150 \mathrm{~g}$ a.i. $\mathrm{L}^{-1}$ of tiabendazole $+25 \mathrm{~g}$ a.i. $\mathrm{L}^{-1}$ fludioxonil) at the dose of $0.002 \mathrm{~L} \mathrm{kgv}^{-1}$, and cyantraniliprole insecticide $\left(600 \mathrm{~g}\right.$ a.i. $\left.\mathrm{L}^{-1}\right)$, at the dosage of $0.0012 \mathrm{~L} \mathrm{kgv}^{-1}$ of seeds.

The sowing was carried out on January 8, 2019, with a density of 16 seeds per meter and spaced of $0.5 \mathrm{~m}$ between rows. A conventional cultivar Ansc 89109 was employed for the sowing. The treatments have been applied one day later of sowing, following the "plant and apply" method, as the manufacturer's recommendations. For the application of treatments, a Jacto model 2500-star uniport sprayer with a 
capacity of 2,500 L, equipped with a $28 \mathrm{~m}$ boom with 56 nozzles spaced $0.5 \mathrm{~m}$ apart was used. The post-emergence molecule clethodim was applied at a dosage of $108 \mathrm{~g}$ a.i. ha-1 in all treatments, 25 days after sowing

\section{Variables collected from soybean culture}

At 14, 21, 32, and 37 days after sowing (DAS), the stem diameter and height of soybean were assessed in ten plants located in the four central lines of each plot, totaling 40 plants per repetition. The stem diameter $(\mathrm{mm})$ was obtained at the height of the cotyledon node, in the opposite direction to their insertion, using a digital caliper. The plant height $(\mathrm{cm})$ was obtained by measuring the neck up to the last apical bud through graduated measuring tape.

\section{Phytosociological surveys}

For assessing the effects of the herbicides on the weed community, two phytosociological surveys were conducted, at 21 and 32 DAS, aiming to understand the weed infestation dynamics as a function of treatment. The phytosociological survey consisted of four launches of an inventory square with an area of $0.25 \mathrm{~m}^{2}$ for each experimental unit. The plants were identified with the help of specialized literature (Lorenzi, 2008) and quantified to estimate phytosociological indices.

\section{Productivity}

At 115 days after sowing, the useful area of the plots was harvested and the yields were compared. The number of plants per linear meter, number of pods per plant, and the number of grains per plant were determined. The yield was calculated and expressed in $\mathrm{kg} \mathrm{ha}^{-1}$, after correcting the water content of the seeds to $13 \%$.

\section{Statistical analysis}

Phytosociological indices evaluated:

Average number of individuals (IND)

$$
\begin{aligned}
& =\frac{\text { total number of individuals }}{\text { total number of squares obtained }} \\
& \text { Density (D) }=\frac{\text { total number of individuals per species }}{\text { unit of area }\left(\mathrm{m}^{2}\right)} \\
& \text { Relative density }(\mathrm{Dr})=\frac{\text { Density of species } \mathrm{x} 100}{\text { total density of all species }} \\
& \text { Frequency (F) } \\
& =\frac{\text { number of squares containing the species }}{\text { total number of squares obtained }} \\
& \text { Relative frequency }(\mathrm{Fr})=\frac{\text { species frequency } \times 100}{\text { total species frequency }} \\
& \text { Abundance (A) } \\
& \text { total number of individuals per species } \\
& =\frac{\text { total number of squares that contain the species }}{\text { thetal }} \\
& \text { Relative abundance (Ar) } \\
& \text { Importance Value Index (IVI) } \\
& =\frac{\text { species abundance } \times 100}{\text { total abundance of all species }} \\
& =\text { relative frequency }+ \text { relative density } \\
& + \text { relative abundance } \\
& =\frac{\text { value index of the importance of the species x } 100}{\text { value index of total importance of all species }}
\end{aligned}
$$

According to the methodology proposed by MuellerDombois and Ellenberg, (1974).

The degree of aggregation in the distribution of species in the area was calculated using the dispersion index $(\mathrm{DI})=$ $\sigma^{2} / \mu$, which pointed out the ratio of variance $\left(\sigma^{2}\right)$ to the mean $(\mu)$ (Cardina et al., 1995; Shiratsuchi et al., 2005). The DI assessed how weed species were distributed in the area. It was considered that DI values greater than the unit (1.0) characterized an aggregate distribution.

As the distribution of weeds does not meet the basic assumptions of statistical inference, phytosociological variables were analyzed using descriptive statistics." Due to the fact that weeds occur randomly and spontaneously, the evaluation of phytosociological parameters is performed by descriptive statistics, since the inferences methods require population measurements (means) and means tests, which require that the variances be homogeneous. Making it difficult to use in systems where the occurrence of phenomena and biological responses are erratic. In this sense, the evaluation of phytosociological indices is carried out using the methodology proposed by Mueller-Dombois \& Ellenberg (1974), as described in the work methodology.

The data were submitted to analysis of variance by the $F$ test and the means compared by the Tukey test at $5 \%$ probability, using the $R^{\circledast}$ software. Except for phytosociological indices that were analyzed by descriptive statistics.

\section{Conclusions}

The application of S-metolachlor (1,152 g a.i. ha-1) demonstrated to be efficient for the pre-emergence control of weed competition in commercial soybean crops. Through the application of this treatment, the conventional cultivar Ansc 89109 produced between 2 and 4 bags per hectare, more than plots treated with diclosulam (35 g a.i. ha-1) + imazethapyr (164.8 $\mathrm{g}$ a.i. ha-1) and diclosulam (42 $\mathrm{g}^{-1 . i . ~ h a^{-1}}$ ) + imazethapyr (164.8 $\mathrm{g}$ a.i. ha-1). It is not recommended to apply a superdoses of diclosulam ( $42 \mathrm{~g}$ a.i. ha-1) in a mixture with imazethapyr (164.8 $\mathrm{g}$ a.i. ha- ${ }^{-1}$ ) due to eminent agronomic, environmental and economic risks.

\section{Acknowledgments}

The Fundação de Amparo à Pesquisa e ao Desenvolvimento Tecnológico no Estado do Maranhão (FAPEMA), for the financial resource, Edital Universal 002/2019, process 795/19.

\section{References}

Adegas FS, Oliveira MF, Vieira OV, Prete CEC, Gazziero DLP, Voll E (2010) Levantamento fitossociológico de plantas daninhas na cultura do girassol. Planta Daninha. 28:705-716.

Aisenberg GR (2015) Atributos fisiológicos na cultura da soja e controle de plantas daninhas em função da aplicação de herbicidas (master's thesis). Federal University of Pelotas, Brazil.

Bianchi MA, Fleck NG, Agostinetto D, Rizzardi MA (2011) Interferência de Raphanus sativus na produtividade de cultivares de soja. Planta Daninha. 29:783-792.

Bueno A, Moreira A, Balbinot Junior AA, Carvalho C, Gazzoni D, Marcelino-Guimarães FC, Henning FA, Neumaier N (2013) Tecnologias de produção de soja: Região Central do Brasil 2014. Embrapa Soja, Londrina.

Cardina J, Sparrow DH, Mccoy EL (1995) Analysis of spatial distribution of common lambsquarters (Chenopodium album) in no-till soybean (Glycine max). Weed Science. 43:258-268.

Cardoso AD, Viana AES, Barbosa RP, Teixeira PRG, Cardoso Júnior, NS, Fogaça, JJNL (2013) Levantamento fitossociológico de plantas daninhas na cultura da mandioca em Vitória da Conquista, Bahia. Bioscience Journal. 29:1130-1140. 
Chiapinotto DM, Schaedler CE, Fernandes JPS, Andres A, Lamego, FP (2017) Cross-resistance of rice flatsedge to ALS-inhibiting herbicides. Planta Daninha. 35:1-12.

Chiapinotto DM, Schaedler CE, Lamego FP, Andres A, Tambara AL, Jaskulski WL (2019) Alternativas de controle químico de junquinho resistente aos herbicidas inibidores da ALS. Revista Brasileira de Herbicidas. 18:1-7.

CONAB - Companhia Nacional de Abastecimento (2019) Acompanhamento da safra brasileira: grãos, Primeiro levantamento. Available in: <https://www.conab.gov.br/infoagro/safras/graos/boletim-da-safra-de-graos?start=10> Acessed in: april of 2020.

Damalas CA (2004) Herbicide tank mixtures: common interaction. International Journal of Agriculture \& Biology. 6:209-212, 2004.

Dantas JS, Marques Júnior J, Martins Filho MV, Resende JMDA, Camargo LA, Barbosa RS (2014) Gênese de solos coesos do leste maranhense: relação solo-paisagem. Revista Brasileira de Ciência do Solo. 38:1039-1050.

Fialho CMT, Santos JB, Freitas MAM, França, AC, Silva AA, Santos EA (2011) Fitossociologia da comunidade de plantas daninhas na cultura da soja transgênica sob dois sistemas de preparo do solo. Scientia Agraria. 12: 9-17.

Freitas RS, Ferreira LR, Berger PG, Silva AC, Cecon PR, Silva MP (2006) Manejo de plantas daninhas na cultura do algodoeiro com S-metolachlor e trifloxysulfuron-sodium em sistema de plantio convencional. Planta Daninha. 24:311-318.

Gazola T, Dias MF, Belapart D, Castro EB, Bianchi L (2016) Efeitos do diclosulam na soja cultivada em solos de diferentes classes texturais. Revista Brasileira de Herbicidas.15:353-361.

IBGE - Instituto Brasileiro de Geografia e Estatística (2018) Produção Agrícola Municipal. Available in: https://sidra.ibge.gov.br/tabela/5457\#resultado. Acessed in: march of 2020.

Inoue MH, Mendes KF, Santana CTC, Possamai ACS (2011) Atividade residual de herbicidas pré-emergentes aplicados em solos contrastantes. Revista Brasileira de Herbicidas. 10:232-242.

INMET - Instituto Nacional de Meteorologia (2019) Dados históricos anuais. Available

in: <https://portal.inmet.gov.br/dadoshistoricos> Acessed in: march of 2020.

Kappes C, Arf MV, Arf O, Gitti, DDC, Ferreira JP (2012) Resposta da crotalária a épocas e subdoses de aplicação de glifosato. Bioscience Journal. 28:373-383.

Lamego FP, Ruchel Q, Kaspary TE, Gallon M, Basso, CJ, Santi A L (2013) Habilidade competitiva de cultivares de trigo com plantas daninhas. Planta Daninha. 31:521-531.

Lopes KAL, Silva MS, Costa LS, Silva TF, Costa TV, Almeida EIB, Oliveira IR, Freitas JRB, Sousa WS, Oliveira LBT (2020) Spatial Distribution of Weed Seed Banks in the Agricultural Field and Anthropized Cerrado. Journal of Agricultural Studies. 8:480-497.

Lopes KAL, Silva M S, Costa LS, Oliveira AKS, Silva EA, Almeida EIB, Oliveira IR, Oliveira LBT, Sousa, WS, Freitas JRB (2020) Fitossociologia do banco de sementes de plantas daninhas em campo agrícola e vegetação de cerrado. Revista Ibero-Americana de Ciências Ambientais. 11:362-370.

Lorenzi, H. (2008) Plantas daninhas do Brasil: terrestre, aquáticas, parasitas e tóxicas. 4.ed. Instituto Plantarum: Nova Odessa. p. 678.

Machado FG, Jakelaitis A, Gheno EA, Oliveira Júnior RS, Rios FA, Franchini LHM, Lima MS (2016) Performance de herbicidas para o controle de plantas daninhas no sorgo. Revista Brasileira de Herbicidas. 15:281-289.
Maranhão - Governo do Estado do Maranhão (2002) Gerência de Planejamento e Desenvolvimento Econômico - GEPLAN. Atlas do Maranhão. Universidade Estadual do Maranhão: São Luís. 39p.

Martins MB, Benetti C, Ely MA, Rosa RF, Saturno AM, Concenco G, Andres A (2019) Estratégias para controle de gramíneas na cultura da soja cultivada em terras baixas. Paper presented at the 11rd Congresso Brasileiro de Arroz Irrigado, Epagri/Sosbai, Balneário Camboriú, 13-16 august 2019.

Mendes KF, Olivatto GP, Sousa RN, Junqueira LV, Tornisielo VL (2019) Natural biochar effect on sorption-desorption and mobility of diclosulam and pendimethalin in soil. Geoderma. 347:118-125.

Mueller-Dombois D, Ellenberg $H$ (1974) Aims and methods of vegetation ecology. 1rd edn. John Wiley e Sons: New York. p. 547.

Nunes AL, Vidal RA (2008) Persistência do herbicida S-metolachlor associado ao glyphosate ou paraquat em plantio direto. Planta Daninha. 26:385-393.

Oliveira AR, Freitas SP (2008) Levantamento fitossociológico de plantas daninhas em áreas de produção de cana de açúcar. Planta Daninha. 26:33-46.

Paes HMF (2010) Estudo fitossociológico e georreferenciamento na cultura de girassol em função de diferentes manejos (doctoral's thesis). State Univesity of the North Fluminense Darcy Ribeiro, Brazil.

Radwan DEM (2012) Salicylic acid induced alleviation of oxidative stress caused by clethodim in maize (Zea mays L.) leaves. Pesticide Biochemistry and Physiology. 102:182-188.

Riar DS, Tehranchian P, Norsworthy JK, Nandula V, McElroy S, Srivastava, V, Chen S, Bond JA, Scott RC (2015) Acetolactate synthase- inhibiting, herbicide-resistant rice flatsedge (Cyperus iria): cross-resistance and molecular mechanism of resistance. Weed Science. 63:748-757.

Rodrigues BN, Almeida FS (2011) Guia de herbicidas. IAPAR: Londrina, $697 \mathrm{p}$.

Rodrigues-Costa ACP, Martins D, Costa NV, Campos CF, Martins CC, Pereira MRR, Silva, JIC (2011) Seletividade de herbicidas aplicados em pré-emergência em gramíneas forrageiras. Planta Daninha. 29:625-633.

Salomão PEA, Ferro MAS, Ruas WF (2020) Herbicidas no Brasil: uma breve revisão. Research, Society and Development. 9:e32921990.

Sanchotene DM, Dornelles SHB, Bolzan TM, Voss, HMG, Escobar OS, Leon CB, Muller, EN, Shimóia EP (2017) Desempenho de diferentes herbicidas pré-emergentes para controle de Euphorbia heterophylla na cultura da soja. Perspectiva. 41:7-15.

Shiratsuchi LS, Fontes, JRA, Resende AV (2005) Correlação da distribuição espacial do banco de sementes de plantas daninhas com a fertilidade dos solos. Planta Daninha. 23:429-436.

Silva JAA, Santos MA, Karam D (2010). Doses de imazethapyr e nicosulfuron para o manejo de grama-batatais (Paspalum notatum). Paper presented at the 27rd Congresso Brasileiro da Ciência das Plantas Daninhas, Sociedade Brasileira da Ciência das Plantas Daninhas, Ribeirão Preto, 19-23 july 2010.

Souza RG, Cardoso DBO, Mamede MC, Hamawaki OT, Sousa LB (2019) Desempenho agronômico de soja, sob interferência de plantas infestantes. Cultura Agronômica. 28:194-203.

Souza JC, Cavalcante AMLN, Gonçalves GS, Albertino, SMF, Silva JF (2014) Screening e dose-resposta de herbicidas à malva e juta. Revista Brasileira de Herbicidas. 13:258-263.

Vidal RA, Theisen G, Fleck NG (1999) Herbicidas Inibidores de ALS Aplicados na Fase de Florescimento da Soja. Revista Brasileira de Agrociência. 5:142-146. 